\title{
Clinton's horizon beyond the Pacific
}

Last week's folksy gathering off Seattle should not be mistaken for the country fair it has been represented as. Clinton's immediate goals (and success) notwithstanding, it marks the beginning of an historic process.

IT is now more than 20 years since the late Dr Herman Kahn began preaching in the United States the importance of what is called the 'Pacific rim'. Then, he had little evidence to support his case: the productivity of Hong Kong and Taiwan in manufacturing industry, the remarkable recovery of Japan from the Second World War, the emergence of Singapore as a trading centre and the signs, already abundant, that South Korea had set its sights on bettering Japan. From before the Bush presidency, the United States has been alternately angry with and fearful of Japan for its success in the black arts of high-quality mass production which, when technology was simpler, made the Remington rifle, the Singer sewing-machine and the Model-T Ford the symbols of US prowess. Now, uncomfortably, there is China just over the horizon. Kahn had spotted that as well, but the speed of China's economic growth would have surprised him. President Bill Clinton was wise to dig out a lumberjack shirt and hie off to the Pacific northwest a week ago.

Indeed, it was also clever of him, and for several reasons. First, this was not the first meeting of its kind, as may have been inferred from words put about, but the fourth in a series of talking-shops between Pacific governments which the United States has not previously invested with importance. Second, on this occasion, the United States played host, even if offshore. Third, the event was so managed that those who felt left out (including India and Pakistan) were numerous (or at least vocal) enough to give those invited a sense of belonging to an exclusive club. But the real cleverness is that Clinton has left everybody guessing what his motives were. Is he really after a Pacific Trading Area or merely suggesting to the countries of Western Europe what may happen if they do not sign some version of the latest instalment of the General Agreement on Tariffs and Trade (the Uruguay round of GATT) by mid-December?

Even so, the meeting off Seattle will not be the last. Little of substance may have been agreed, but the precedent is bound to set a trend. Those invited will want to meet again, perhaps in more accessible and even comfortable surroundings, while the United States and China each have a need of some multilateral way of talking to each other that does not compromise their principles. What better setting than a talking-shop about technology and trade, in which all parties have a vital interest, that may also serve as a vehicle for an accommodation between the only two credible superpowers of the next decade (beginning in 2001) and may avoid the polarization of the past half-century? Clinton may have played a flesh-pressing politician's hunch in travelling to Seattle, but there will be a next time (somewhere else) and he will then have serious business on his mind.

What will it be? China's relationship with the nonproliferation regime (see Nature 366, 189; 1993) must certainly be settled by the end of next year. The middling-term agenda is complicated by the rapid souring (early in the 1970s) of the Nixon-Kissinger rapprochement with China, whose chief effect (in China's eyes) has been to leave a cohort of bright students stranded in the United States.

The best way forward for the next decade's two superpowers would be to put technology and trade on the footing that strategic weapons enjoyed at the beginning of the Cold War. Then, from early in the 1960s, the Soviet Union and the United States began talking to each other informally about the technology of each other's nuclear weapons. Only when there was a sufficient mutual understanding was it possible, early in the 1970s, for the Soviet Union and the United States to contemplate an agreement on strategic arms control - the premature START-I agreement signed by President Richard M. Nixon at Vladivostock in 1972 (but never ratified). Of course, the same tortuous process will be necessary now in dealings with China, but the agenda should be broader. The past few years have shown that questions such as the expropriation of foreign companies and the exploitation of intellectual property rights can be almost as divisive as the threat of nuclear war.

\section{Tea-leaves tell nothing}

The Council for Science and Technology is not likely to meet the needs of the British science community.

LiTTLE can be gleaned about the British government's intentions towards research from the announcement last week that the Director-General of Research Councils (no doubt 'DGRC' in civil service minutes) will be Sir John Cadogan and of the names of the part-time (but paid) chairmen of the three research councils for which there is at present no incumbent. The government is doing what it has (since the early summer) said it would: splitting the Science and Engineering Research Council into two unequal parts (called the Particle Physics and Astronomy Research Council, PPARC, and the Engineering and Physical Sciences Research Council) and providing each with a structure that 